\title{
Wildlife damage and cultivated land abandonment: Findings from the mountainous areas of Chongqing, China
}

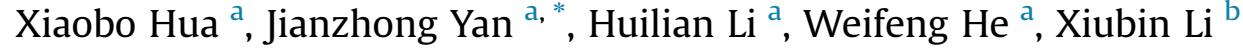 \\ a College of Resources and Environment, Southwest University, Chongqing, 400716, China \\ ${ }^{\mathrm{b}}$ Institute of Geographic Sciences and Natural Resources Research, CAS, Beijing, 100101, China
}

\section{A R T I C L E I N F O}

\section{Article history:}

Received 13 August 2015

Received in revised form

2 March 2016

Accepted 5 March 2016

Available online 21 March 2016

\section{Keywords:}

Human-wildlife conflict

Cultivated land use decision-making

Land abandonment

Livelihood

Mountainous area

China

\begin{abstract}
A B S T R A C T
Human-wildlife conflict (HWC) is a growing global issue that seriously threatens agricultural production and livelihoods. Studying the relationship between wildlife damage, land use, and livelihood enables us to understand the dilemma facing current wildlife protection and ecological restoration policies and to amend existing policies effectively. Using participatory rural appraisal (PRA), quantitative analysis, and a Multilevel Logit regression model, this paper analyzed land use and livelihoods among 160 households subject to wild boar (Sus scrofa) damage in four villages within Youyang County in the poor mountainous areas of Chongqing, China. The findings showed the following: (i) wild boars in Youyang County were responsible for large-scale crop and property damage; (ii) cultivated land abandonment has become a significant trend in land use, and the most important perceived driver for abandoning farmland is the land plot's vulnerability to wild boar damage; (iii) when protecting cultivated land plots, households tend to protect those plots that are close to the road, have larger land area, and have a slight or abrupt slope; however, households with more members working in non-farm labor, more female agricultural workers, and/or higher non-farm income are more inclined to abandon protection of their plots. This paper discusses seven main measures that are frequently adopted by farmers to protect their crops and livestock and are perceived by these farmers as the most effective and sensible countermeasures.
\end{abstract}

(C) 2016 Elsevier Ltd. All rights reserved.

\section{Introduction}

Human-wildlife conflict (HWC) has increased in recent years, becoming a major worldwide concern (Distefano, 2005; Madden, 2004; Messmer, 2000; Osborn and Parker, 2002; Thapa, 2010). HWC has significant impacts on land use practices and agricultural production. For example, in Asia, snow leopards (Uncia uncia), lions (Panthera leo), leopards (Panthera pardus), tigers (Panthera tigris), wild boars (Sus scrofa), and elephants (Elephas maximus) are often regarded as destroyers of livestock and crops. Local farmers have suffered major financial losses annually due to crop damage by wildlife (Distefano, 2005; Madhusudan, 2003; Sekhar, 1998; Sreekar et al., 2013; Yu et al., 2009). Inhabitants who suffer from wildlife damage around the world often take measures, using both indigenous knowledge and modern technology, to protect local farming (Hartter et al., 2011; Hough, 1993; Thapa, 2010).

\footnotetext{
* Corresponding author. College of Resources and Environment, Southwest University, No.1 Tiansheng Road, Beibei District, Chongqing, 400716, China.

E-mail address: yanjzswu@126.com (J. Yan).
}

In the context of HWC, numerous studies attempt to better understand the relationship between wildlife and livelihood security. The themes of these studies can be generally divided into two important categories: (i) the damages to crops and loss of livestock caused by wildlife and the effectiveness of countermeasures taken by individuals or households (Hough, 1993; Messmer, 2000; Thapa, 2010; Wang et al., 2006); (ii) the gap between wildlife protection polices and livelihood, and how to design compensation schemes to protect farmers' rights of development (Madhusudan, 2003; Rondeau and Bulte, 2007). However, very little research has been done on the connections among wildlife damage, cultivated land use, and household livelihood that could contribute to further thinking on current wildlife protection policies and ecological restoration policies.

Although the causes of the wild boar problem in China are still unknown, wild boar populations are now overly abundant in several provinces, resulting in damage to agricultural crops and local livelihoods, and raising concerns among agricultural producers, wildlife managers, and natural resource professionals (Cai et al., 2008; Li et al., 2010a, 2010b; Zhou et al., 2008). Restricted 
by wildlife protection policy, limited technology and knowledge, and the lack of a compensation scheme, farmers find themselves in a vulnerable position with regard to wild boars. For instance, in China, the State Forestry Administration (SFA) has published two documents-Wildlife Conservation Law and Lists of State-Protected Terrestrial Species That Are Beneficial and of Important Economic and Scientific Research Value in 1988 (first amended in 2004 and again in 2009) and 2000, respectively (Li, 2007). In this context, killing and injuring of wild animals listed in the protection index is prohibited. Furthermore, there is no compensation policy with respect to HWC in rural China, where small-scale farming plays a significant economic role. Just as in other countries, Chinese farmers protect their crops using indigenous knowledge and methods; for example, increasing the number of people patrolling a field has reduced the incidence of wild boar damage around a giant panda nature reserve in the Qinling Mountains in Shaanxi Province, China (Cai et al., 2008). In Eastern Liaoning Province, farmers there use traditional, non-lethal measures to prevent wild boar damage, such as setting off firecrackers and patrolling at night (Yu et al., 2009). However, other traditional methods, such as lethal hunting methods, are banned by wildlife conservation guidelines inside a nature reserve, though local people lack broad knowledge, technology, and equipment needed to deal with wild boar in alternative ways (Cai et al., 2008; Dickman, 2010; Osborn and Parker, 2002; Thapa, 2010).

In China, dominant off-farm earnings and lower profits in agricultural production make farming unattractive to most farmers. Nowadays, more and more agricultural laborers migrate to seek offfarm employment, which has resulted in a labor shortage in rural China (Knight et al., 2011; Zhang et al., 2011), and cultivated lands, forming the basic cultivation for food-subsistence, are left to women and elderly people (Chang et al., 2011; Lichtenberg and Ding, 2008). From 2008, the wages for off-farm employment increased quickly, which has even attracted women and elderly people to seek off-farm employment. The farmers now face the choice between protecting cropland from wild boars and seeking off-farm employment. If they choose the latter, they are inclined to abandon croplands.

There are numerous reports on the theme of "wild boar invasion and human retreat" (Cai et al., 2008; Li et al., 2010a, 2010b); however, there is a lack of empirical information and research on the connection between HWC and land abandonment at the microlevel. The goal of this study is to present an empirical study of how increasing opportunities within the labor force will drive local farmers to stop protecting their crops and abandon their cultivated land that has been damaged by wildlife.

\section{Materials and methods}

\subsection{Study area selection}

Youyang is a National Key Poverty Alleviation County and belongs to an ecologically fragile zone (Chen, 2009; Editorial Committee of Chorography of Youyang County, 2002; Editorial Committee of Overview of Youyang County, 2008; Hua et al., 2013, 2014). Youyang County lies in Southeastern Chongqing (Fig. 1). Its geographic coordinates are $108^{\circ} 18^{\prime} 25^{\prime \prime}-109^{\circ} 19^{\prime} 02 \mathrm{E}$, $28^{\circ} 19^{\prime} 28^{\prime \prime}-29^{\circ} 24^{\prime} 18^{\prime \prime} \mathrm{N}$, and it has a total area of 5159.3 square kilometers. There are three types of landforms within the county: middle mountain (800-1895 m), low mountain (600-800 m), and trough valley $(263-600 \mathrm{~m})$, each accounting for approximately $54.86 \%, 21.14 \%$, and $24 \%$ of the total land area, respectively. Youyang has a four-season humid monsoon subtropical climate. Topoclimate is quite prominent in this area. The annual average temperature decreases from $17.1{ }^{\circ} \mathrm{C}$ in the lowlands $(263 \mathrm{~m})$ to $8.1{ }^{\circ} \mathrm{C}$ at the highest point ( $1895 \mathrm{~m}$ ). The county has jurisdiction over 38 towns and 278 administrative villages, and the county seat is located in the town of Zhongduo.

We chose two townships-Maoba and Muye-as the study area due to their severe crop loss, such as maize, damaged by wild boar, based on an early household survey (Li et al., 2014). Maoba Township is located to the North of Youyang County. The township is $38 \mathrm{~km}$ away from the county seat, with an elevation of 703-1540 $\mathrm{m}$ and a total area of 143 square kilometers. We selected Tiancang Village and Shuanglong Village as sampled villages in Maoba Township. Muye Township is located to the northeast of Youyang County. The township is $61 \mathrm{~km}$ away from the county seat, with an average elevation of $850 \mathrm{~m}$ and a total area of 130 square kilometers. We selected Li'er Village and Dabanying Village as sampled villages in Muye Township.

\subsection{Data collection}

We carried out a tracking survey in August 2013 based on a household survey conducted in Youyang County in July 2012 (Li et al., 2014). In the previous survey, we found that human-wild boar conflicts perceived by farmers were very serious in the sampled villages (Li et al., 2014). Hence, we designed and conducted the supplementary investigation. Our study adopted participatory rural appraisal (PRA) tools including in-depth interviews, focus group discussions, and questionnaires. First, we performed in-depth interviews with some informants, including heads of administrative villages and natural villages, elderly persons, and township officials. These in-depth interviews mainly focused on the overall conditions as well as changes of livelihood activities, cultivated land use, and the main crops damaged by wild boar in the areas. In addition, we gleaned some information about the amount of residents who suffered great loss by wild boar damage in the study areas in 2012. Second, we conducted focus group discussions to obtain information such as socioeconomic conditions and institutional backgrounds, farmers' perceptions on the crop damage, cultivated land abandonment caused by wild boars, and the means of protection taken by local farmers. Based on these two methods, we obtained a general understanding of our targets at the village level, which was helpful in conducting household surveys. Third, we developed a detailed quantitative questionnaire using preliminary information gathered during the first two stages to obtain information on the following two topics: (i) crop damage and cultivated land abandonment, and (ii) the means taken by farmers to protect their crops. The survey contents included basic information of investigated households, such as family size, education level, and allocation of labor force; land use, including land area, type, and grade, as well as cultivated land abandonment and "Grain for Green"; and crop damage and land abandonment caused by wildlife, and the means taken by households to protect their crops. The main respondent was the head of each household, with other family members providing supplementary information. The interview time for each household was 1-2 h. We performed the interviews separately by two interviewers. In total, we selected 160 households randomly from four administrative villages (37 in Tiancang, 40 in Shuanglong, 39 in Li'er, and 44 in Dabanying).

\subsection{Statistical analysis}

Wild boar, showing remarkable flexibility in its ecological and behavioral traits, almost always are active at night when human presence is low (Li et al., 2013; Ohashi et al., 2013). Therefore, we presume that all cultivated land plots are faced with wild boar damage during the overnight hours. When analyzing the cultivated 


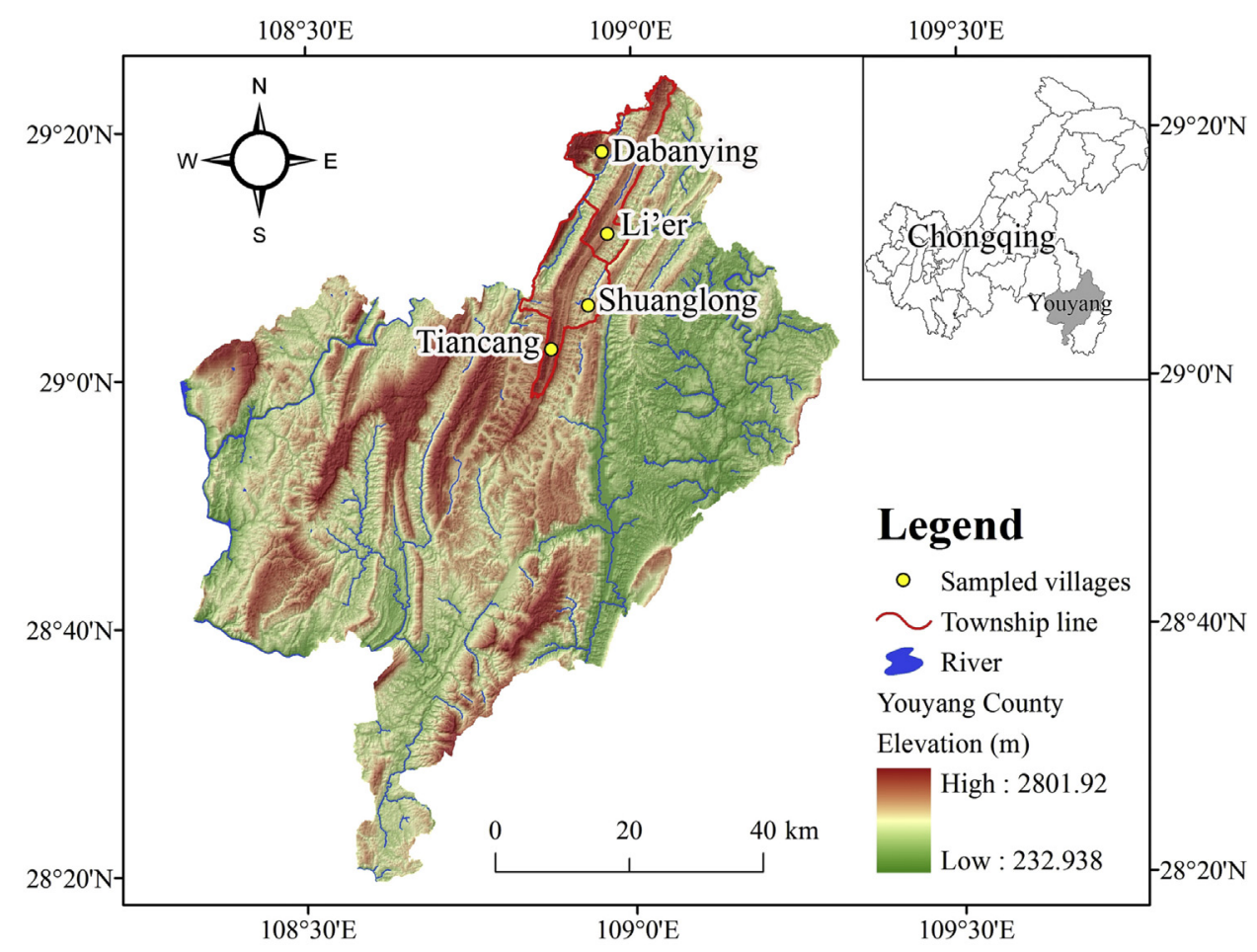

Fig. 1. Location of the study area.

land plots protected by farmers, we explore why some land plots are given priority to be protected, while the others are not protected. The decision to protect the cultivated land plots from wild boar damage is plotted as a binary outcome model. We analyze the data as follows.

(1) Dependent variables: The decision to protect land plots is a binary variable; for this reason, we define the dependent variables as $P=1$ (to protect land plot) and $P=0$ (not to protect land plot).

(2) Explanatory variables: Explanatory variables mainly cover the characteristics at household level and land plot level (Table 1). The household level variables include total labor force (Labor), nonfarm labor force (NfLabor), agricultural labor force with good health (Health), females in the agricultural labor force (Female), non-farm income (NfIncome), the age of household head (Age), the education level of household head (Education), and the cultivated land area per capita $($ AreaH). The land plot level variables include land area (AreaL), land type (Type), land grading (Grade), irrigation conditions (Irrigate), the distance to the house (Distance), road access (Road), access to forest (Forest), and perceived slope of land (Slope).

(3) Multilevel logit regression model: The Multilevel logit model specification follows research by Overmars and Verburg (2006). In this case, we apply the models with two levels: level 1 data refer to land plot characteristics and level 2 data refer to household characteristics. The subsequent models are fixed effect models, with the following two levels:

$\operatorname{Prob}(y=1 \mid \beta)=\varphi$

$$
\begin{aligned}
\log \left(\frac{\varphi}{1-\varphi}\right)= & \gamma_{00}+\gamma_{01} * \text { Labor }+\gamma_{02} * \text { NfLabor }+\gamma_{03} * \text { Health } \\
& +\gamma_{04} * \text { Female }+\gamma_{05} * \text { NfIncome }+\gamma_{06} * \text { Age } \\
& +\gamma_{07} * \text { Educaiton }+\gamma_{08} * \text { AreaH }+\gamma_{10} * \text { AreaL } \\
& +\gamma_{20} * \text { Type }+\gamma_{30} * \text { Grade }+\gamma_{40} * \text { Irrigate } \\
& +\gamma_{50} * \text { Distance }+\gamma_{60} * \text { Road }+\gamma_{70} * \text { Foreat } \\
& +\gamma_{80} * \text { Slope }+\mu_{0}+\mu_{6} * \text { Road }+\mu_{8} * \text { Slope }
\end{aligned}
$$

We performed the analysis with HLM 6.08 Trial software.

\subsection{Limitations of the study}

This paper makes an important contribution to literature on the connection between wildlife damage and land use; however, there are also two main limitations. One is the limitation of cross-section data. The appearance of wild boars is uncertain, and the number of wild boars in a given area and that affect a specific plot of land are difficult to estimate. For these reasons, it is difficult to reflect the trajectory of cultivated land abandonment caused by wild boars and the associated increase in labor, in terms of time invested. Another limitation is that it is difficult to distinguish the driving forces of cultivated land abandonment and identify the most important factor from households' perception by using quantitative measurements. This type of data, however, is crucial to future policy-making for land use decisions in mountainous areas.

\section{Results}

\subsection{Background of the sample households and land plots}

In the study area, a total of 160 households were investigated, including 656 individuals, of which 362 were males and 294 were 
Table 1

Descriptions of variables affecting whether household take measures to protect crops from wild boar damage at land plot level $\left(\mathrm{N}_{\text {households }}=160\right.$ and $\mathrm{N}_{\text {land }}$ plots $=700$ ).

\begin{tabular}{|c|c|c|c|c|c|c|c|}
\hline Variables & Abbreviation & $\begin{array}{l}\text { Variable } \\
\text { types }\end{array}$ & Definition & $\operatorname{Min}^{\mathrm{a}}$ & $\operatorname{Max}^{\mathrm{b}}$ & Mean & $\mathrm{SD}^{\mathrm{c}}$ \\
\hline \multicolumn{8}{|l|}{ Household level } \\
\hline Total labor force & Labor & Continuous & $\begin{array}{l}\text { The number of total labor force per household. It includes agricultural labor } \\
\text { and non-farm labor with labor capacity. Those who are too old, with poor } \\
\text { health or waiting for employment are not included. }\end{array}$ & 0.000 & 6.000 & 2.631 & 1.169 \\
\hline $\begin{array}{l}\text { Non-farm labor } \\
\text { force }\end{array}$ & NfLabor & Continuous & $\begin{array}{l}\text { The number of non-farm labor force per household. The non-farm labor } \\
\text { means out migration for job opportunity at least for } 3 \text { months. }\end{array}$ & 0.000 & 4.000 & 1.000 & 1.028 \\
\hline $\begin{array}{l}\text { Agricultural labor } \\
\text { force with good } \\
\text { health }\end{array}$ & Health & Continuous & The number of Agricultural labor force with good health per household. & 0.000 & 3.000 & 0.669 & 0.822 \\
\hline $\begin{array}{l}\text { Female } \\
\text { agricultural } \\
\text { labor force }\end{array}$ & Female & Continuous & The number of female agricultural labor force per household. & 0.000 & 2.000 & 0.738 & 0.508 \\
\hline Non-farm income & Income & Continuous & Income from non-farm activities. (Yuan) & 0.000 & 348000.000 & 28147.575 & 37412.171 \\
\hline $\begin{array}{l}\text { The age of } \\
\text { household head }\end{array}$ & Age & Continuous & The interviewer gave the age of head of household at the end of 2012 . & 32.000 & 84.000 & 58.563 & 12.226 \\
\hline $\begin{array}{l}\text { The education } \\
\text { level of } \\
\text { household head }\end{array}$ & Education & Ordinal & $\begin{array}{l}1 \text { means illiteracy, } 2 \text { means primary school, } 3 \text { means middle school, } \\
4 \text { means high school and } 5 \text { means college. }\end{array}$ & 1.000 & 4.000 & 2.000 & 0.673 \\
\hline $\begin{array}{l}\text { The land area } \\
\text { under } \\
\text { cultivating per } \\
\text { capita }\end{array}$ & AreaH & Continuous & The land area under cultivating per capita of a household. $(\mathrm{mu})^{\mathrm{d}}$ & 0.050 & 14.680 & 1.520 & 1.760 \\
\hline \multicolumn{8}{|l|}{ Land plot level } \\
\hline Land area & AreaL & Continuous & The area of each land plot. (mu) & 0.050 & 60.000 & 1.244 & 2.719 \\
\hline Land type & Type & Ordinal & Paddy values 1 , and dry land values 2 . & 1.000 & 2.000 & 1.687 & 0.464 \\
\hline Land grading & Grade & Ordinal & $\begin{array}{l}\text { The land grading of each land plot is shown in land contract certificate of } \\
\text { household. } 1 \text { means the highest and } 5 \text { means the lowest quality, 2-4 range } \\
\text { from high to low. }\end{array}$ & 1.000 & 5.000 & 2.284 & 0.810 \\
\hline $\begin{array}{l}\text { Irrigation } \\
\text { conditions }\end{array}$ & Irrigate & Binary & If the land plot can be irrigated well, then values 1 , otherwise, values 0 . & 0.000 & 1.000 & 0.107 & 0.310 \\
\hline $\begin{array}{l}\text { The distance to } \\
\text { house }\end{array}$ & Distance & Continuous & $\begin{array}{l}\text { The distance from the land plot to house of household who own this land. } \\
(\mathrm{km})\end{array}$ & 0.000 & 4.000 & 0.487 & 0.499 \\
\hline Access to road & Road & Binary & $\begin{array}{l}\text { If the land plot is close to country road, then values } 1 \text {, otherwise, values } 0 \text {. Be } \\
\text { close to road, farmers can easily cultivate and protect it. }\end{array}$ & 0.000 & 1.000 & 0.484 & 0.500 \\
\hline Access to forest & Forest & Binary & $\begin{array}{l}\text { If the land plot has access to forest, then values } 1 \text {, otherwise, values } 0 \text {. Be close } \\
\text { to forest, it is likely to be damaged by wild boar. }\end{array}$ & 0.000 & 1.000 & 0.566 & 0.496 \\
\hline $\begin{array}{l}\text { Perceived slope of } \\
\quad \text { land }\end{array}$ & Slope & Ordinal & $\begin{array}{l}\text { If the slope is flat, then values } 0 \text {. The slight or abrupt values } 1 \text {. The farmers } \\
\text { were asked to think back to their perception of slope. }\end{array}$ & 0.000 & 1.000 & 0.337 & 0.473 \\
\hline
\end{tabular}

Note.

a Min = Minimum.

b Max = Maximum

c $\mathrm{SD}=$ Standard deviation.

d $1 \mathrm{mu}=1 / 15 \mathrm{hm}^{2}$.

Source: Authors' survey.

Table 2

Household and land information in study area.

\begin{tabular}{|c|c|c|c|c|c|c|}
\hline \multicolumn{2}{|l|}{ County village } & \multicolumn{2}{|c|}{ Maoba township } & \multicolumn{2}{|c|}{ Muye township } & \multirow[t]{2}{*}{ Total } \\
\hline & & Tiancang & Shuanglong & Li'er & Dabanying & \\
\hline \multirow[t]{2}{*}{ Individuals } & Male & 92 & 83 & 79 & 108 & 362 \\
\hline & Female & 72 & 70 & 66 & 86 & 294 \\
\hline \multirow[t]{3}{*}{ Labor force } & Agriculture & 43 & 59 & 53 & 53 & 208 \\
\hline & Part-time farming & 25 & 8 & 11 & 9 & 53 \\
\hline & Non-farm & 39 & 28 & 35 & 58 & 160 \\
\hline \multirow[t]{3}{*}{ Numbers of land plots } & "Grain for Green" & 66 & 78 & 59 & 62 & 265 \\
\hline & Cultivated land abandoned & 161 & 128 & 167 & 225 & 681 \\
\hline & Cultivating $^{\mathrm{a}}$ & 168 & 181 & 170 & 181 & 700 \\
\hline \multicolumn{2}{|c|}{ Average numbers of owed land ${ }^{\mathrm{b}}$ plots per household } & $9.81(4.05)^{e}$ & $8.33(3.48)$ & $10.05(4.50)$ & $10.66(4.00)$ & $9.73(4.07)$ \\
\hline \multicolumn{2}{|c|}{ Average area of owned land per household $/ \mathrm{mu}^{\mathrm{c}}$} & $13.15(8.57)$ & $14.05(7.37)$ & $18.89(13.61)$ & $33.02(58.50)$ & $20.23(32.66)$ \\
\hline \multicolumn{2}{|c|}{ Average area under cultivating per household/mu } & $5.01(3.65)$ & $5.23(3.83)$ & $9.04(12.96)$ & $2.81(2.67)$ & $5.44(7.34)$ \\
\hline \multicolumn{2}{|c|}{ Average cultivated land area per land plot/mu } & $1.10(1.04)$ & $1.16(1.20)$ & $2.07(5.06)$ & $0.68(1.08)$ & $1.24(2.72)$ \\
\hline \multicolumn{2}{|c|}{ Average cultivated land grading ${ }^{\mathrm{d}}$ per land plot/mu } & $1.87(0.79)$ & $2.36(0.84)$ & $2.39(0.74)$ & $2.49(0.74)$ & $2.28(0.81)$ \\
\hline
\end{tabular}

Notes.

a The land plots with cultivating contain land plots household owned and rented in from others.

b The owned land contain cultivated land, abandoned land, land for "Grain for Green" and land rented out to others.

c $1 \mathrm{mu}=1 / 15 \mathrm{hm}^{2}$.

d The land grading is shown in land contract certificate of household.

e Standard deviation is in parentheses.

Source: Authors' survey. 
females (Table 2). In terms of labor allocation, agricultural labor contains the largest number of people, while part-time farming contains the least. In addition, more laborers engage in non-farm activities, such as migrant work, than in business enterprises. In terms of land plots, we divided the sampled plots into three categories: land plots under the "Grain for Green" policy; abandoned land plots; and land plots currently being cultivated. Cultivated land abandonment is widespread in the mountainous areas of this region. The average land area owned by each household is 9.73 plots and $20.23 \mathrm{mu}$ ( $1 \mathrm{ha}=15 \mathrm{mu}$ ); however, the average cultivated land area per household is only $5.44 \mathrm{mu}$. To an extent, this indirectly shows a high level of cultivated land abandonment; furthermore, cultivated land plots are often small and fragmented, with an average grading of 2.28 , which is between 2 (good quality) and 3 (moderate quality).

\subsection{Crop damage and cropland abandonment}

According to the answers of interviewees and the recent published empirical findings (Hua et al., 2014; Li et al., 2014), wild boars in Youyang County were responsible for large-scale crop and property damage. Table 3 shows the extent and costs of crop damage caused by wild boars. There were 335 damaged cultivated land plots, accounting for $47.86 \%$ of total land plots, among which 175 were damaged by wild boars, which accounted for $25 \%$ of total cultivated land plots. The average area damaged by wild boars per household was $0.95 \pm 1.87 \mathrm{mu}$, accounting for $22.80 \pm 0.30 \%$ of total cultivated land plots. The serious human-wild boar conflicts resulted in significant property losses for the sampled households. The average cost of the damage per capita was 173.92 RMB Yuan (according to Chongqing Survey Yearbook 2012, the net annual income of rural residents per capita in Youyang County was 4539.37 RMB Yuan).

Cultivated land abandonment has become a significant trend in land use. In terms of the types of abandoned cultivated land, the number of abandoned dry lands was nearly three times that of abandoned paddy lands (Table 3). Fig. 2 presents the perceived

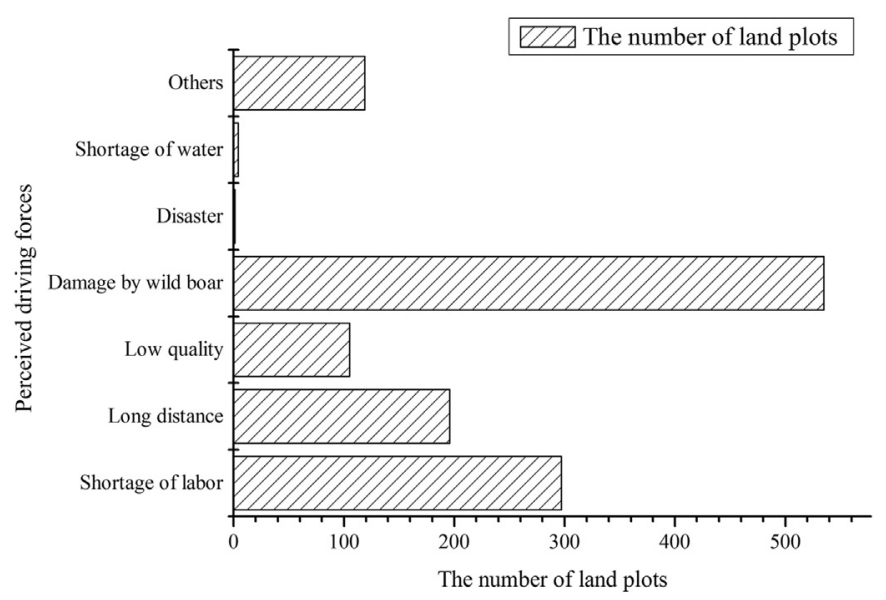

Fig. 2. Households' perceived driving forces behind cultivated land abandonment. Notes: Land plot abandonment may have more than one reason. For example, a farmer may abandon one land plot because of both labor shortage and long distance to home. Therefore, the total numbers shown in Fig. 2 are larger than that of the total number of abandoned cultivated land plots.

driving forces linked to cultivated land abandonment. The most important driver for abandoning farmland is the land plot's vulnerability to wild boar damage. Other causes include increasing forest area due to "Grain for Green," "peer effects" in abandoning land use (one abandons his farmland following the others' abandoning), etc.

\subsection{Measures to protect crops}

Maize, sweet potato, and potato are the most popular crops grown by farmers. However, these crops are also favorite foods of wild boars. Faced with the dilemma between wild boar damage and agriculture production, farmers have to devise adaptation

Table 3

The crop damage and cultivated land abandonment caused by wild boar in study area.

\begin{tabular}{|c|c|c|c|c|c|c|}
\hline \multicolumn{2}{|l|}{ County village } & \multicolumn{2}{|l|}{ Maoba } & \multicolumn{2}{|l|}{ Muye } & \multirow[t]{2}{*}{ Total } \\
\hline & & Tiancang & Shuanglong & Li'er & Dabanying & \\
\hline \multicolumn{7}{|l|}{ Crop damage } \\
\hline \multirow[t]{4}{*}{ Damaged land plots ${ }^{\mathrm{a}}$} & Numbers & 77 & 66 & 87 & 105 & 335 \\
\hline & Percentage of damaged land/\% & 45.83 & 36.46 & 51.18 & 58.01 & 47.86 \\
\hline & Damaged land by wild boar & 37 & 25 & 47 & 66 & 175 \\
\hline & Percentage of damaged land by wild boar/\% & 22.02 & 13.81 & 27.65 & 36.46 & 25.00 \\
\hline \multirow[t]{2}{*}{ Crop damage } & $\begin{array}{l}\text { Average area damaged by wild boar per } \\
\text { household/mu }\end{array}$ & $1.03(1.70)^{\mathrm{b}}$ & $0.91(1.37)$ & $1.38(3.01)$ & $0.56(0.67)$ & $0.95(1.87)$ \\
\hline & The percent of damaged land by wild boar $/ \%$ & $24.05(0.32)$ & $15.90(0.25)$ & $23.63(0.31)$ & $27.27(0.32)$ & $22.80(0.30)$ \\
\hline \multicolumn{2}{|c|}{ Average cost for damage by wild boar per household/Yuan } & $641.35(997.05)$ & $338.00(602.76)$ & $887.72(1206 / 79)$ & $417.91(601.51)$ & $564.12(897.75)$ \\
\hline \multicolumn{7}{|c|}{ Cultivated land abandonment } \\
\hline \multirow[t]{2}{*}{ Type of abandoned cultivated land } & Paddy & 38 & 36 & 46 & 55 & 175 \\
\hline & Dry land & 123 & 92 & 121 & 170 & 506 \\
\hline \multirow[t]{4}{*}{ Current situation } & Grass & 104 & 42 & 115 & 101 & 362 \\
\hline & Bush & 24 & 51 & 12 & 64 & 151 \\
\hline & Forest & 32 & 35 & 37 & 57 & 161 \\
\hline & Occupied & 1 & 0 & 3 & 3 & 7 \\
\hline \multirow[t]{2}{*}{ Whether to cultivate in the future } & Yes & 7 & 3 & 7 & 4 & 21 \\
\hline & No & 154 & 125 & 160 & 221 & 660 \\
\hline \multicolumn{2}{|l|}{ Average distance to house $/ \mathrm{km}$} & $1.10(1.20)$ & $2.48(2.42)$ & $1.11(1.36)$ & $1.19(1.04)$ & $1.39(1.59)$ \\
\hline \multicolumn{2}{|c|}{ Average area per abandoned land plot/mu } & $1.55(1.52)$ & $1.84(1.44)$ & $1.63(1.95)$ & $2.88(8.55)$ & $2.06(5.12)$ \\
\hline \multicolumn{2}{|c|}{ Average land grading per abandoned land plot } & $2.39(0.87)$ & $2.72(0.63)$ & $2.59(0.72)$ & $2.68(0.67)$ & $2.59(0.74)$ \\
\hline
\end{tabular}

Notes.

a Damaged land plots contain the land damaged by floods, drought, geology disaster, crop pest, freeze injury, wildlife, and the others.

b Standard deviation is in parentheses.

Source: Authors' survey. 
strategies to protect their crops (there were 250 protected land plots), since hunting as a means of wild boar control is forbidden in China. There were four commonly used methods for crop protection (Fig. 3): (i) Building tents: Some farmers build tents a in which they can protect their crops at night. Farmers stay in these tents from 8:00 pm to 6:00 am the next day to guard their crops, from June to August for maize, May to September for sweet potatoes, and March to June for potatoes. This method is effective, but results in fatigue of the farmers; (ii) Scaring devices: Firecrackers, fires, scarecrows, ox horns, and loud speakers are used by some farmers to scare wild boars; (iii) Planting herbs or tobacco: Wild boars are sensitive to the smell of tobacco and certain herbs. In the study area, some farmers rented adjacent land plots to plant tobacco, and wild boars rarely appear there; (iv) Using barbed wire fencing or net wire: Although it is effective, it also presents a danger to domestic livestock and farmers themselves at night.

\subsection{Econometric results}

The study result shows five out of the fourteen independent variables significantly influenced the protection behavior taken by households based on a multilevel logit regression model. The
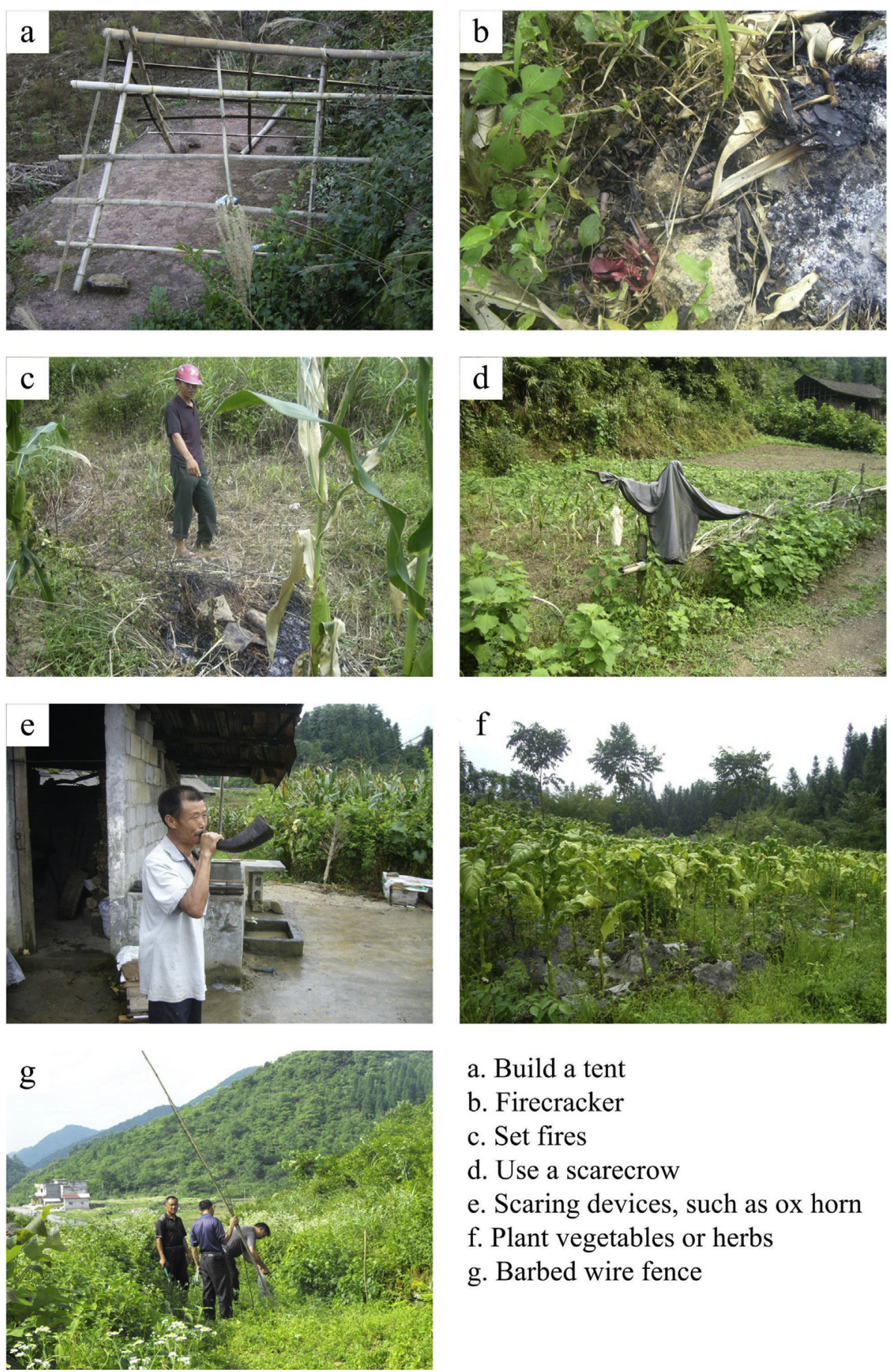
a. Build a tent
b. Firecracker
c. Set fires
d. Use a scarecrow
e. Scaring devices, such as ox horn
f. Plant vegetables or herbs
g. Barbed wire fence

Fig. 3. Various means of protection taken by local farmers in the study area (Photos taken in December 2011, July 2012, and August 2013 by Xiaoyan Yuan, Xiaobo Hua, and Huilian Li). 
factors influencing the adaptation strategies to human-wild boar conflict are presented in Table 4.

\subsubsection{At the household level}

There were three main factors influencing protection behavior at household level: (i) Non-farm labor force: The increase in nonfarm labor force has negative effects on the protection means taken by farmers; for example, households with more non-farm labor forces tend to protect their land plots less; (ii) Female agricultural labor force: A greater number of females in the agricultural labor force can have negative effects on the protection means taken by farmers; (iii) Non-farm income: The non-farm income per household has negative effects on the protection means taken by farmers, and is often correlated to non-farm labor force.

\subsubsection{At the land plot level}

There were three main factors influencing protection behavior at the land plot level: (i) Per capita cultivated land area: This can positively influence the protection means taken by farmers, as farmers tend to protect land plots with larger land area per capita; (ii) Road access: Being close to a road has significant and positive effects on the protection measures taken by farmers, as wild boar tend to avoid areas with high human activity; (iii) Perceived slope of land: The perceived slope of land significantly and positively influenced the protection measures taken by farmers when it was away from forests (i.e., wild boars' natural habitat).

\section{Discussions}

\subsection{Wildlife damage and rethinking current policies}

We found that overly abundant wild boars were responsible for crop damage, which inspired us to rethink the current wildlife protection and agricultural policies. The World Wildlife Fund for Nature states that "one of the simplest ways to mitigate conflict without affecting elephant behavior or population size is to compensate people for the damage they have suffered or would have suffered had they not protected their crop" (Bulte and Rondeau, 2007). Numerous compensation and insurance schemes have been implemented to address conflicts between humans and wildlife (Pérez and Pacheco, 2006), some of which have achieved relative success, such as a reduction in killing of lions and elephants

Table 4

Parameter estimation results of impacts of land plot characteristics on adaptation strategies $\left(\mathrm{N}_{\text {households }}=160\right.$ and $\left.\mathrm{N}_{\text {land plots }}=700\right)$.

\begin{tabular}{lclrl}
\hline Fixed effect & Coefficient & Standard error & T-ratio & P-value \\
\hline Household level & & & & \\
Intercept & -1.169 & 1.012 & -1.155 & 0.250 \\
Labor & 0.416 & 0.297 & 1.400 & 0.164 \\
NfLabor & $-\mathbf{0 . 6 2 6}^{* *}$ & 0.289 & -2.169 & 0.031 \\
Health & 0.071 & 0.161 & 0.439 & 0.661 \\
Female & $-\mathbf{0 . 6 3 5}^{*}$ & 0.382 & -1.664 & 0.098 \\
Income & $-\mathbf{0 . 0 0 0}^{*}$ & 0.000 & -1.808 & 0.072 \\
Age & 0.001 & 0.011 & 0.090 & 0.929 \\
Education & -0.079 & 0.168 & -0.473 & 0.637 \\
AreaH & -0.039 & 0.047 & -0.840 & 0.402 \\
Land plot level & & & & \\
AreaL & $\mathbf{0 . 0 2 8}^{* *}$ & 0.014 & 1.989 & 0.047 \\
Type & -0.091 & 0.169 & -0.539 & 0.590 \\
Grade & 0.118 & 0.094 & 1.255 & 0.210 \\
Irrigate & -0.170 & 0.231 & -0.738 & 0.461 \\
Distance & -0.067 & 0.139 & -0.482 & 0.630 \\
Road & $\mathbf{1 . 2 2 8}^{* * *}$ & 0.192 & 6.393 & 0.000 \\
Forest & -0.226 & 0.181 & -1.250 & 0.212 \\
Slope & $\mathbf{0 . 6 1 0}^{* * *}$ & 0.176 & 3.468 & 0.001 \\
\hline
\end{tabular}

Notes: ${ }^{* * *},{ }^{* *}$ and ${ }^{*}$ represent significant level at $1 \%, 5 \%$, and $10 \%$, respectively.
(Dickman et al., 2011; Madhusudan, 2003; Osborn and Parker, 2002; Rondeau and Bulte, 2007). China still lacks such compensation or insurance schemes. The Agricultural Insurance Regulations (nongye baoxian tiaoli), conducted on March 1, 2013, argues that it is necessary to regulate agricultural insurance activities, protect the legitimate rights and interests of the parties engaged in agricultural insurance activities, improve farmers' capacity to withstand risks, and promote the healthy development of the agricultural insurance business. However, losses caused by wild boar are not within the scope of current compensation regulations; therefore, it is necessary to enact new compensation and insurance schemes that include damage by wildlife. Furthermore, local governments and farmers both suggest that wild boar should be removed from the list of those species under state protection.

\subsection{Protection measures for wildlife damage}

Because the wild boar issue has only emerged over the last ten years, the farmers have just begun to learn how to protect their crops and livestock through adopting often very simply measures. The farmers have to invest too much time and energy, which exhausts their resources over the long term. Cai et al. (2008) reported the ineffectiveness of most of the methods currently used to protect crops. Therefore, the government should introduce more effective measures and provide technological and financial support for implementation by farmers.

The protection measures taken in this case are similar to cases in other developing countries. Thapa (2010), for example, listed some means most often used by local respondents to protect their crops at Bardia National Parks, Nepal, which include modern means, such as barbed wire fencing, as well as traditional means, such as biofencing, and he also evaluated the effectiveness of these means. In one case study in India, the most common mitigation measures for crop protection were night watching (46\%), fencing (34\%), and scare devices (34\%) (Karanth et al., 2013).

Specifically, when using the tent-building method, Cai et al. (2008) found that all sample households spent long amounts of time protecting maize in Shanxi Province, China. Studies from Uganda (Hill, 1997; Naughton-Treves, 1998), Zambia (Marks, 1976), Tanzania (Gillingham and Lee, 2003), and India (Rao et al., 2002) also documented smallholder farmers at risk of wildlife cropdamage who adopted a similar strategy of guarding their farm plots to minimize losses. The majority of households moved out of the village during the high-risks months to live in temporary shelters on their farm-plots to protect their crops. A study by Gillingham and Lee (2003) found that crop fields left unguarded for longer periods of time suffered higher and more severe damage from wildlife than more frequently guarded fields. However, the investment of time and labor required to ensure effective protection against wildlife crop-damage represented considerable losses of opportunity for the farmers.

For scaring devices, use of campfires to repel wildlife during the night was the most common measure taken in Nanda Devi Bioshphere Reserve, India (Rao et al., 2002). In a case in Ghana, noise, fire, and an on-site caretaker are the preferred measures (Harich et al., 2013). In Western African national parks, villagers often perform bush burning to deter wild animals (Hough, 1993).

For planting herbs or tobacco, in a case in Jiangxi Province, China, a number of farmlands have been converted from rice planting to cotton planting, because cotton is more resistant to the damages caused by wild boars (Li et al., 2010a, 2010b). Another study reports that it may also be effective if crops such as trichomatous cereals, which are less attractive to wild boars, are planted close to forests (Schley et al., 2008). In Africa, one promising approach is the use of deterrents based on chili pepper, such 
as chili-greased fences (Harich et al., 2013; Osborn and Parker, 2002; Sitati and Walpole, 2006).

For using barbed wire fencing or net wire, the use of wire mesh for excluding animals from crop fields may not be a viable option because of the high cost to farmers in developing countries (Pérez and Pacheco, 2006); however, cases in Japan show that electric fencing was the most effective countermeasure (Honda et al., 2009; Reidy et al., 2008; Saito et al., 2011; Vidrih and Trdan, 2008). The use of electric fencing is also considered to be highly effective because of its aversive conditioning abilities.

\subsection{Cultivated land abandonment and influencing factors}

Generally, the main factors influencing protection behaviors include characteristics of non-farm activities, distance to road, land size, and topographic features. At the household level, if there are more females in the agricultural labor force within a household, they are not likely to protect the land plots, as females were found to be more afraid of wild animals than males (Li et al., 2010a, 2010b). Non-farm income can be seen as a reflection of labor migration, to some extent. Generally, more workers migrating for off-farm employment can bring more non-farm income, but it may also lead to a shortage of agricultural labor forces. Cai et al. (2008) found that some households involved in ecotourism began to decrease their crop planting because of heavy damage by wild boars.

At the land plot level, farmers tend to protect the cultivated land plots that are close to roads. Relatively convenient road access gives farmers easier access to their cultivated land plots (Honda and Sugita, 2007; Saito et al., 2011) and helps to avoid wild boar damage due to higher population densities, indicating that wild boars avoid human activities. However, some respondents saw wild boars active in residential areas, and during the study period, five people were injured. In poor mountainous areas, cultivated land is the most important natural asset for a household's livelihood, and it is often spread fragmentally with a slight or abrupt slope, always near forest, making it vulnerable to damage by wild boars. Wild boars may prefer to forage in croplands adjacent to the forest, which is their natural habitat. In order to meet the demands of agriculture production and livestock, most land plots that have relatively good or moderate quality and a slight or abrupt slope are cultivated by smallholders.

Based on the econometric results, we have reason to assume that cultivated land use scenarios in the future will increase in opportunity based on the cost of labor force and labor migration. In our previous study, based on available data from 975 households, we found that 650 of these households (accounting for $66.67 \%$ of the total sampled households) relied on their main income source from non-farm works, which accounted for greater than $50 \%$ of total family income showing households' livelihood relying on non-farm employment (Li et al., 2014). In addition, remaining farmers are primarily older people and women who have relatively low labor capacity (Li et al., 2014). Farmers can make choices about whether to protect crops and earning money from agriculture, or to rely on non-farm job opportunities (Hua and Yan, 2015). With the increase in non-farm employment, labor force shortages, and constant wildlife damage in rural areas, farmers are trending toward giving up protecting crops and are abandoning their cultivated land. Therefore, in order to guarantee local food security, we should further understand farmers' willingness to either protect or abandon the cultivated land. We should also seek to understand which land plots should get preferential protection in the future, and clarify farmers' livelihood transitions, which, as mentioned above, all require long-term observation.

\section{Conclusions and policy implications}

Using participatory rural appraisal (PRA), quantitative analysis and a Multilevel Logit regression model, this paper analyzed the land use and livelihoods of 160 households dealing with wild boar damage in four typical villages of Youyang County in the poor mountainous areas of Chongqing, China. The results give some evidence of HWC in China. All of the analysis results show the following: (i) wild boars in Youyang County are responsible for large-scale crop and property damage; (ii) cultivated land abandonment has become a significant trend in land use, and the most important perceived driver for abandoning farmland is the vulnerability of the land plot to damage by wild boars; (iii) when protecting the cultivated land plots, households tend to protect the cultivated land plots that are closer to the road, have larger land area, and have a slight or abrupt slope; however, households may give up protecting the land plots if there is a higher non-farm labor force among them, more female agricultural workers, and higher non-farm income. These findings provide important insights on the relationship between wildlife damage and cultivated land abandonment in a restoring environment context.

Based on our findings, we assert that the government should adjust their current policies related to the wildlife protection, make new policy recommendations for the future, and take necessary top-down protection measures to eliminate the negative effects of wild animals. Ultimately, the government should factor wildlife damage into the revision of the current Agricultural Insurance Regulations and needs to consider (currently unavailable) compensation schemes for wildlife damage.

\section{Acknowledgment}

The authors acknowledge the financial support of the National Natural Science Foundation of China (No. 41161140352). We would like to thank the village cadres in the sampled villages for their helps and supports in this research. We thank Dr. Ying Zhang of IGSNRR for her help with model specification. We also thank all the investigated villagers, who are patient with our endless questions.

\section{References}

Bulte, E., Rondeau, D., 2007. Compensation for wildlife damages: habitat conversion, species preservation and local welfare. J. Environ. Econ. Manag. 54, 311-322.

Cai, J., Jiang, Z., Zeng, Y., Li, C., Bravery, B.D., 2008. Factors affecting crop damage by wild boar and methods of mitigation in a giant panda reserve. Eur. J. Wildl. Res. 54, 723-728.

Chang, H., Dong, X.-y., MacPhail, F., 2011. Labor migration and time use patterns of the left-behind children and elderly in rural China. World Dev. 39, 2199-2210.

Chen, J., 2009. Study on Rural Chronic Poverty in Ecological Fragile Region_- - Based on Monitoring Evidence from 600 National Poverty Alleviation County. Economic Science Press, Beijing.

Dickman, A.J., 2010. Complexities of conflict: the importance of considering socia factors for effectively resolving human-wildlife conflict. Anim. Conserv. 13 (5), $458-466$.

Dickman, A.J. Macdonald, E.A. Macdonald, D.W., 2011. A review of financial instruments to pay for predator conservation and encourage human-carnivore coexistence. Proc. Natl. Acad. Sci. 108, 13937-13944.

Distefano, E., 2005. Human-wildlife Conflict Worldwide: Collection of Case Studies Analysis of Management Strategies and Good Practices. SARD. Initiative Report. FAO, Rome.

Editorial Committee of Chorography of Youyang County, 2002. Youyang Chorography. Chongqing Publishing House, Chongqing.

Editorial Committee of Overview of Youyang County, 2008. Overview of Youyang County. The Ethical Publishing House, Beijing.

Gillingham, S., Lee, P.C., 2003. People and protected areas: a study of local perceptions of wildlife crop-damage conflict in an area bordering the Selous Game Reserve, Tanzania. Oryx 37, 316-325.

Harich, F.K., Treydte, A.C., Sauerborn, J., Owusu, E.H., 2013. People and wildlife: conflicts arising around the Bia Conservation Area in Ghana. J. Nat. Conserv. 21, $342-349$.

Hartter, J., Goldman, A., Southworth, J., 2011. Responses by households to resource scarcity and human-wildlife conflict: issues of fortress conservation and the 
surrounding agricultural landscape. J. Nat. Conserv. 19, 79-86.

Hill, C.M., 1997. Crop-raiding by wild vertebrates: the farmer's perspective in an agricultural community in western Uganda. Int. J. Pest Manag. 43, 77-84.

Honda, T., Miyagawa, Y., Ueda, H., Inoue, M., 2009. Effectiveness of newly-designed electric fences in reducing crop damage by medium and large mammals. Mammal. Study 34, 13-17.

Honda, T., Sugita, M., 2007. Environmental factors affecting damage by wild boars (Sus scrofa) to rice fields in Yamanashi Prefecture, central Japan. Mammal. Study 32, 173-176.

Hough, J.L., 1993. Why burn the bush? Social approaches to bush-fire management in West African national parks. Biol. Conserv. 65, 23-28.

Hua, X., Yan, J., 2015. The risk of protection: the dilemma between wildlife protection and cropland use under ecological restoration. Glob. Land Proj. GLP News $12,70-74$

Hua, X., Yan, J., Yuan, X., 2014. The Impact of the Rise of Labor Opportunity Cost on Farmers' Land Abandonment Behavior in Hilly Areas: A Case Study of Youyang County in Chongqing. Journal of Southwest University (Natural Science Edition) 36, pp. 111-119.

Hua, X., Yan, J., Zhou, C., Chen, L., 2013. Marginalization of agricultural land use in hilly areas and its explanation from the livelihood strategy of farmers: a case study on Youyang County. Acta Sci. Nat. Univ. Pekin. 49, 1047-1055.

Karanth, K.K., Gopalaswamy, A.M., Prasad, P.K., Dasgupta, S., 2013. Patterns of human-wildlife conflicts and compensation: insights from Western Ghats protected areas. Biol. Conserv. 166, 175-185.

Knight, J., Deng, Q., Li, S., 2011. The puzzle of migrant labour shortage and rura labour surplus in China. China Econ. Rev. 22, 585-600.

Li, L., Shi, J., Wang, J., Gao, Y., Wang, L., Wang, J., Ying, X., 2013. Factors influencing wild boar damage in Taohongling National Nature Reserve in China: a model approach. Eur. J. Wildl. Res. 59 (2), 179-184.

Li, L., Wang, J., Shi, J., 2010a. Human-wild boar (Sus scrofa) conflict: current status. Influence factors and management recommendations. Sich. J. Zool. 29, 642-648.

Li, L., Wang, J., Shi, J., Wang, Y., Liu, W., Xu, X., 2010b. Factors influencing local people's attitudes towards wild boar in Taohongling National Nature Reserve of Jiangxi Province, China. Procedia Environ. Sci. 2, 1846-1856.

Li, P.J., 2007. Enforcing wildlife protection in China the legislative and political solutions. China Inf. 21 (1), 71-107.

Li, Z., Yan, J., Hua, X., Xin, L., Li, X., 2014. Factors influencing the cultivated land abandonment of households of differenttypes: a case study of 12 typical villages in Chongqing Municipality. Geogr. Res. 33, 721-734.

Lichtenberg, E., Ding, C., 2008. Assessing farmland protection policy in China. Land Use Policy 25, 59-68.

Madden, F., 2004. Creating coexistence between humans and wildlife: global perspectives on local efforts to address human-wildlife conflict. Hum. Dimen. Wildl. 9 (4), 247-257.

Madhusudan, M., 2003. Living amidst large wildlife: livestock and crop depredation by large mammals in the interior villages of Bhadra Tiger Reserve, south India. Environ. Manag. 31, 0466-0475.

Marks, S.A., 1976. Large Mammals and a Brave People: Subsistence Hunters in Zambia. Transaction Publishers.

Messmer, T.A., 2000. The emergence of human-wildlife conflict management: turning challenges into opportunities. Int. Biodeterior. Biodegrad. 45, 97-102. Naughton-Treves, L., 1998. Predicting patterns of crop damage by wildlife around Kibale National Park, Uganda. Conserv. Biol. 12, 156-168.

Osborn, F.V., Parker, G.E., 2002. Community-based methods to reduce crop loss to elephants: experiments in the communal lands of Zimbabwe. Pachyderm 33, $32-38$.

Ohashi, H., Saito, M., Horie, R., Tsunoda, H., Noba, H., Ishii, H., Kuwabara, T., Hiroshige, Y., Koike, S., Hoshino, Y., Toda, H., Kaji, K., 2013. Differences in the activity pattern of the wild boar Sus scrofa related to human disturbance. Eur. J. Wildl. Res. 59 (2), 167-177.

Overmars, K.P., Verburg, P.H., 2006. Multilevel modelling of land use from field to village level in the Philippines. Agric. Syst. 89, 435-456.

Pérez, E., Pacheco, L.F., 2006. Damage by large mammals to subsistence crops within a protected area in a montane forest of Bolivia. Crop Prot. 25, 933-939.

Rao, K., Maikhuri, R., Nautiyal, S., Saxena, K.G., 2002. Crop damage and livestock depredation by wildlife: a case study from Nanda Devi Biosphere Reserve, India. J. Environ. Manag. 66, 317-327.

Reidy, M.M., Campbell, T.A., Hewitt, D.G., 2008. Evaluation of electric fencing to inhibit feral pig movements. J. Wildl. Manag. 72, 1012-1018.

Rondeau, D., Bulte, E., 2007. Wildlife damage and agriculture: a dynamic analysis of compensation schemes. Am. J. Agric. Econ. 89, 490-507.

Saito, M., Momose, H., Mihira, T., 2011. Both environmental factors and countermeasures affect wild boar damage to rice paddies in Boso Peninsula, Japan. Crop Prot. 30, 1048-1054.

Schley, L., Dufrêne, M., Krier, A., Frantz, A.C., 2008. Patterns of crop damage by wild boar (Sus scrofa) in Luxembourg over a 10-year period. Eur. J. Wildl. Res. 54, 589-599.

Sekhar, N.U., 1998. Crop and livestock depredation caused by wild animals in protected areas: the case of Sariska Tiger Reserve, Rajasthan, India. Environ. Conserv. 25, 160-171.

Sitati, N.W., Walpole, M.J., 2006. Assessing farm-based measures for mitigating human-elephant conflict in Transmara District, Kenya. Oryx 40, 279-286.

Sreekar, R., Mohan, A., Das, S., Agarwal, P., Vivek, R., 2013. Natural windbreaks sustain bird diversity in a tea-dominated landscape. PloS One 8, e70379.

Thapa, S., 2010. Effectiveness of crop protection methods against wildlife damage: a case study of two villages at Bardia National Park, Nepal. Crop Prot. 29, 1297-1304.

Vidrih, M., Trdan, S., 2008. Evaluation of different designs of temporary electric fence systems for the protection of maize against wild boar (Sus scrofa L., Mammalia, Suidae). Acta Agric. slov. 91, 343.

Wang, S.W., Curtis, P.D., Lassoie, J.P., 2006. Farmer perceptions of crop damage by wildlife in Jigme Singye Wangchuck National Park, Bhutan. Wildl. Soc. Bull. 34, 359-365.

Yu, H., Wu, J., Fan, Y., 2009. Survey on damages by wild boar in East Liaoning. Chin. J. Wildl. 30, 124-128.

Zhang, X., Yang, J., Wang, S., 2011. China has reached the Lewis turning point. China Econ. Rev. 22, 542-554.

Zhou, X., Ma, J., Zhang, W., Xiao, W., 2008. An investigation of residents' acceptance of wild boar and influencing factors in Hunchun Natural Reserve. Resour. Sci. 30, 876-882. 